\title{
海産無脊椎動物レクチンの構造と機能に関する研究
}

\author{
長崎大学工学部応用化学科 畠 山 智 充
}

生体内に扝いては様々な糖鎖が重要な役割を果たし ているが，糖鎖認識タンパク質としての動物レクチン にも様々なタイプのものが見いだされてきた。これま でに知られている動物レクチンはその構造上の類似性 から，C型，ガレクチン ( $\mathrm{S}$ 型)， P 型, I 型, ペントラ クシンなどのファミリーに分類されており，中でも，活 性に $\mathrm{Ca}^{2+}$ を必要とするC 型レクチンは，種々の耐椎動 物組織や体液中において重要な機能を持つものが知ら れている.一方，無脊椎動物においても，多くの種に レクチンが存在することが知られており，オプソニン 作用などを通して生体防㓡に関与していることが示晙 されているが, 現在のところその構造や機能の詳細が 明らかにされたものは少ない。そこで本研究では，海 産無春椎動物の中でも，棘皮動物に属するマナマコ (Stichopus japonicus) 及びグミ(Cucumaria echinata) から数種類の $\mathrm{Ca}^{2+}$ 依存性レクチンを単離し，その構造 と機能について検討した。

1. マナマコ及びグミの $\mathrm{Ca}^{2+}$ 依存性レクチン マナマコ及びグミ体液から，それぞれ SJL-I，-II ならびに CEL-I〜CEL-IVと名付けた $\mathrm{Ca}^{2+}$ 依存性レク チンを精製した。このうちマナマコの SJL-I とグミの CEL- I 及び-IVに関しては，アミ/酸配列を決定し，配 列相同性の比較を行ったところ，いずれもC型レクチ ンファミリーに属することが明らかになった。ささら， これまでC型レクチンに不可欠と考えられていた $2 つ$ の分子内ジスルフィド結合のうち 1 つが必ずしも重要 ではないことを明らかにした。

一方，グミ体液から精製された分子量 $47 \mathrm{kDa} の$ $\mathrm{Ca}^{2+}$ 依存性レクチン CEL-III はヒトやウサギの赤血球 に加えると速やかな溶血を引き起こすことから，新規 な溶血性レクチンであることが明らかになった。溶血 は pH 7.5 において $5 \mu \mathrm{g} / \mathrm{ml}(0.1 \mu \mathrm{M})$ の CEL-IIIでも 認められたが， $\mathrm{pH}$ が上昇するとともに活性も急激に上 昇し, pH 10 では 20 倍以上の高い溶血活性が見られた。 一方，種々の糖の存在下で活性を調べた結果，N-アセ チルガラクトサミンで最も活性が阻害され，それに続 いて，ラクトースやその他のガラクトース含有糖でも
顕著な阻害が見られた。これらの結果は，CEL-IIIの赤 血球膜表面糖鎖への特異的な結合が溶血活性に重要て あることを示している。そこでこのCEL-IIIの䌅結合特 異性を検討するために，我々が最近開発した，糖固定 化 96 穴マイクロプレートを用いるレクチン活性測定法 によって CEL-IIIの糖結合特異性について検討した. そ の結果，CEL-III との最も強い親和性は N-アセチルガ ラクトサミンで諗められ，次いでラクトースやラクツ ロースなど $\beta-1,4$ 結合をもつガラクトース含有栯で強 い親和性が認められた。この CEL-IIIに対する親和性は， 溶血活性に及ほすこれらの糖の阻害の順序とほほ一致 しており，このことからも，精結合活性が溶血活性と 密接な関係を持つことが示された。

CEL-IIIのアミノ酸配列についても，これまでにその 一部が明らかになったが，C 型レクチン類を含めて，そ れほど高い相同性を示すタンパク質は見いだされなか った。また，CEL-IIIのアミノ酸配列中には約 30 残基 からなる配列の数回にわたる反復が認められ，これま でに知られていない新しいタイプの $\mathrm{Ca}^{2+}$ 依存性レクチ ンであることが示晙された。

\section{CEL-III の溶血機椪}

このように CEL-IIIの $\mathrm{Ca}^{2+}$ 依存性レクチンとしての 性質が，その溶血作用と強く結びついていることは明 らかとなったが，ではどのようにして CEL-III と赫血球 表面梼鎖との結合から溶血へと至るのかを明らかにす る必要がある、そこでまず，CEL-IIIがホスホリパーゼ やプロテアーゼなどの酵素活性により細胞膜を破壊し ている可能性について検討するために，CEL-IIIによっ て処理した後の赤血球膜成分を分析したが，主な脂質 成分にはほとんど変化がなく，また，CEL-III自体にも プロテアーゼ活性は検出されなかったささらに，溶血 活性の至適温度が $10^{\circ} \mathrm{C}$ 付近と低温であることなどから も，醭素的な溶血作用ではないことが示唆された。そ こで次に，ある種の細菌毒素に見られるような，細胞 膜への pore (小孔) 形成による溶血の可能性について 検討した. CEL-III処理後の赤血球膜を抗 CEL-III抗血 清を用いたイムノブロッティングによって調べた結果， 
赤血球膜中に分子量約 $270 \mathrm{kDa}$ の高分子量形として CEL-IIIが結合していることが明らかになった。ささらに， CEL-IIIを赤血球に作用させる際に，分子量 4,000 以上 の多楉類を共存させておくと，見かけ上，溶血は阻止 されるが, 赤血球内部の ATPが流出してくること, ま た，非還元末端にガラクトースや N-アセチルガラクト サミンを含む糖脂質と卵黄ホスファチジルコリンから なるリポソームの内部から CEL-IIIが虽光色素を遊離さ せることなどから，CEL-III脂質膜表面糖鎖と結合後, 膜内でオリゴマーとして pore を形成していることが明 らかになった。すなわち，CEL-IIIは赤血球膜表面の特 異的糖鎖と結合した後に膜内でオリゴマー化し，低分 子イオンが自由に通過できる pore が形成されるが，内 部のへモグロビンなどの高分子イオンは pore を通過で きないために，膜内外の浸透圧差によって赤血球が破 裂するものと考光られる。

\section{CEL-III のオリゴマー形成機構}

CEL-IIIが赤血球表面の糖鎖と結合した後に，膜内で オリゴマーを形成することが明らかになったが, 通常 は水溶性の高いCEL-IIIが膜内でオリゴマー化するため には何らかのコンフォメーション変化が必要であると 考えられる.1つの可能性として，赤血球表面楉鎖との 結合がそのようなコンフォメーション変化の引き金と なることが考えられたことから，CEL-IIIが特異的な糖 と結合した際の構造変化について検討した. その結果, 通常の中性付近では，ラクトースと結合しても CEL-III の構造変化はほとんど認められなかったが，高 $\mathrm{pH}$ 高塩

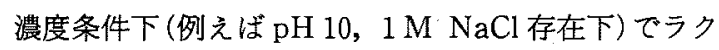
トースと結合すると CEL-IIIは表面疎水性が著しく上昇 するとともに，水溶夜中でも，赤血球膜中で形成した のと同じサイズのオリゴマーを形成することが明らか になった。ささらに円二色性スペクトルの変化から CELIIIの二次構造のうち $\beta$ シート構造が増加しているもの と推定された。このような特異的な糖との結合による 水溶液中でのオリゴマー形成は, ガラクトース含有糖 の中でも，ラクトース，ラクツロース，N-アセチルラ クトサミンなどの $\beta-1,4$ 結合を含む二糖類でのみ認め られたが, N-アセチルガラクトサミンについてはCELIIIに最も強く結合するにも関わらず，オリゴマー化を 引き起こさなかった．このことから，CEL-IIIのオリゴ マー化には単に糖との親和性が関係しているのではな く，そのサイズが重要であり，二糖類以上でなければ CEL-IIIのコンフォメーション変化を引き起こすことが できないのではないかと考えられる。
CEL-IIIオリゴマーのサイズは, SDS-PAGE 上では 6 量体または 7 量体であると推定されたが，溶液中でラ クトースとの結合によって生じたオリゴマーに関して は, 沈降速度法を用いた超遠心分析で $37 \mathrm{~S}$ というかな り大きな值が得られた．また，シンクロトロン放射光 を用いた X 線小角散乱実験からも，1,020 kDa という 值が得られており，水溶液中で CEL-IIIオリゴマーはお そらく 7 量体がさらに 3 個ゆるく会合した，21 量体を 形成しているのではないかと推定される。

\section{4. 細菌毒素との類似性}

CEL-IIIはアルカリ $\mathrm{pH}$ で強い溶血作用を持つレクチ ンとして見いだされたが，本来の生理的役割としては， 外敵からの防御物質としての役割が考えられる。実際, 培養細胞に対する毒性を調べた結果, HeLa 細胞, MDCK 細胞，Vero 細胞などに対して強い毒性が見ら れ, さらにマウス腹腔内注射でも致死量は数十 $\mu \mathrm{g}$ 程度 であることから，生体内においても毒素として存在し， 外からの微生物や捕食者に対する防御物質として働い ている可能性が高いと考光られる。CEL-IIIのような pore 形成タンパク質としてはある種の細菌毒素が知ら れている. 中でも Staphylococcus aureus の $\alpha$-毒素, Aeromonas hydrophila $の$ aerolysin, Bacillus anthracis の anthrax 毒素保護抗原などは, X 線結晶解析 や電子顕微鏡像からそのモノマー及び膜内オリゴマー の立体構造が推定されている．CEL-IIIがこれらの細菌 毒素と類似した pore を形成するのかどうかは不明であ るが，細胞膜レセプターとの結合という最初の段階に 引き続いて, 膜内でオリゴマー化し, pore を形成する という点で類似しており，未だ明らかにされていない これらのタンパク質の会合のメカニズムを解明するた めにもCEL-IIIのオリゴマー形成機構の研究は今後有用 な知見をもたらすものと期待される.

本研究は九州大学農学部農芸化学科生物化学教室及 び長崎大学工学部応用化学科生体機能工学研究室にお いて行ったものであり，長年にわたりご指導いただき ました九州大学名誉教授船津軍喜先生ならびに九州大 学農学部教授山崎信行先生, また暖加い励ましをいた だきました長崎大学工学部教授青柳東彦先生に厚くお 礼申し上げます。また本研究は多くの方々のご協力に よって行われたものであり, 九州大学農学部木村誠助 教授, 毛利孝之助教授, 長崎大学水産学部小田達也助 教授, 理化学研究所藤澤哲郎博士を始め共同研究者の 方々, 研究室大学院生, 卒業生の方々に厚く扔礼申し 上げます。 